ORIGINAL ARTICLE

\title{
Psychological well-being of individuals after divorce: the role of social support
}

\author{
Anna Kołodziej-Zaleska ${ }^{A, B, C, D, E, F}$, Hanna Przybyta-Basista ${ }^{A, B, D, E, F}$ \\ Institute of Psychology, University of Silesia, Katowice, Poland
}

\section{BACKGROUND}

Divorce is a transition period in which divorcing individuals face restructuring of the family system and adjustment to changes. The psychological well-being of divorcees can serve as an important indicator of the adjustment process. The achievement of well-being does not come easily for many reasons, one of which is the experience related to a sense of loss associated with the marriage break-up. Social support is a major relational resource for overcoming the crisis and successfully adjusting to post-divorce life.

\section{PARTICIPANTS AND PROCEDURE}

The sample consisted of 157 individuals after divorce: 120 women and 37 men (mean age $=41.29$ ). Instruments employed in the study included the Sense of Loss Scale (DS), the Interpersonal Support Evaluation List (ISEL), the Oxford Happiness Questionnaire (OHQ-23), and sociodemographic data.

\section{RESULTS}

Our results show that perceived social support is a partial mediator of the relationship between the sense of loss associated with divorce and the psychological well-being of individuals after divorce. For the vast majority of the respondents their parents, friends and acquaintances were the major source of support. About one third of the participants were given support by their siblings and their own children.

\section{CONCLUSIONS}

The study confirms the mediating role of support in building well-being after experiencing loss related to dissolution of marriage. This means that for divorced women and men perceived social support is one of the key resources that have a significant impact on achieving psychological well-being after divorce, since it is related to mitigating the negative impact of the sense of loss associated with marriage break-up.

\section{KEY WORDS}

psychological well-being; divorce; sense of loss; perceived social support

Corresponding AUthor - Prof. Hanna Przybyła-Basista, Institute of Psychology, University of Silesia, 53 Grażyńskiego Str., 40-126 Katowice, Poland, e-mail: przybyla@us.edu.pl

AUthors' CONTRIBUtion - A: Study design - B: Data collection · C: Statistical analysis · D: Data interpretation .

E: Manuscript preparation · F: Literature search · G: Funds collection

to Cite this ARTiCle - Kołodziej-Zaleska, A., \& Przybyła-Basista, H. (2016). Psychological well-being of individuals after

divorce: the role of social support. Current Issues in Personality Psychology, 4(4), 206-216.

RECEIVED 09.07.2016 · REVIEWED 13.08.2016 · ACCEPTED 17.09.2016 · PUBLISHED 18.10.2016 


\section{BACKGROUND}

Divorce affects an increasing number of families worldwide. In Poland, the number of divorces is growing systematically; hence modern families have to face problems and changes once unknown (Amato, 2000, 2014; Clarke-Stewart \& Brentano, 2006; Yárnoz-Yaben, 2013). For both divorcing individuals and their children divorce is a breakthrough transition period, as it involves adjusting to a new life situation and family transitions. It is also an exceptionally challenging life event due to a loss of many sources of familial, financial or tangible support (Beisert, 2000; Błażek, 2014; Coleman, Ganong, \& Leon, 2006; Przybyła-Basista, 2006). Over the last decades, studies on divorce have focused on a range of topics including predictors of divorce, adults' and children's adjustment to divorce, consequences of divorce for men and women, associations between divorce and the well-being of divorced individuals, and interventions for divorcing couples (Amato, 2010). Although the collected knowledge already allows us to draw many conclusions regarding the difficulties and challenges of the functioning of adults and children after divorce, there are still some research gaps, and new suggestions regarding directions of study have been put forward (Amato, 2010). In this article we discuss the role of social support in shaping the psychological well-being of divorced individuals.

Divorce involves a loss of the basic source of support, which for married individuals is the spouse. This entails a loss of many benefits associated with marriage such as emotional support, companionship, a regular sexual partner and economic safety (Amato, 2014). Divorce also involves a loss of identification with the group of a married couple and family, as well as breaking off or limiting contact with the in-laws and siblings of the former spouse, his or her other relatives, friends or acquaintances. Certain stages of divorce such as community divorce or co-parental divorce expose the abundance of difficult experiences associated with severed or weakened ties with individuals (the spouse, children) and entire groups of people (shared friends, acquaintances, neighbors, the former husband's/wife's friends or family) (Bohannan, 1970, see also Przybyła-Basista, 2006). The majority of divorcees reported network losses shortly after the divorce, and in half of the cases these losses were not balanced in the years following the divorce (Terhell, van Groenou, \& van Tilburg, 2004). Also, divorcees often feel less integrated into the local environment (Symoens, Van de Velde, Colman, \& Bracke, 2014). According to Gaffal (2010) a simultaneous decrease in the amount of support from several sources of the social network may cause a destabilizing effect on the personality of an individual. Negative changes are particularly visible with regard to self-esteem. Many divorcees reported lower levels of self-esteem (Symoens et al., 2014) and self-acceptance (Amato, 2000). According to Cohen (1992), most theories dealing with the effects of support on self-esteem assume that support contributes to esteem maintenance.

The loss experienced due to a divorce crisis also affects financial, housing, and property matters. Dividing one household into two without a rise in financial resources undoubtedly contributes to a lower living standard. Supporting two houses and two families often proves insuperable even though both parents work (Crane, 2002). Such a situation is particularly difficult for a parent who has custody of children (i.e. a custodial parent). A decrease in the material living standard is described by divorcees as the basic source of stress and, at the same time, is one of the main risk factors in the process of adjusting to post-divorce changes (Demo \& Fine, 2010; Perrig-Chiello, Hutchison, \& Morselli, 2015).

The reaction to divorce depends on numerous factors and individual reactions that cannot be easily foreseen. However, it might be said that most people experience a sense of loss, sadness, and distress after divorce (Power, 1996). The period immediately after the physical separation is characterized by the highest level of stress. Loneliness and the necessity to cope with life on one's own add to the physical load and health issues (Clarke-Stewart \& Brentano, 2006). Divorcees often experience a deterioration of health status and symptoms of mental disorders (Kitson \& Morgan, 1990; Thuen, 2001). Researchers prove adverse health consequences, i.e., problems with physical, emotional, and social well-being in divorced men and women (Scourfield \& Evans, 2014; Symoens et al., 2014; Zafar \& Kausar, 2014).

For most adults, stressful circumstances related to the dissolution of marriage manifest a decreasing tendency with time, whereas a successful adjustment to new life conditions often requires adopting new roles (Amato, 2014). The readiness to separate from the role of a husband/wife and, hence, the fact that one does not place support in the former marriage, nor does he or she seek it, is of key importance for the process of adjusting to the post-divorce situation and increasing one's well-being (Gaffal, 2010; Kiecolt-Glaser et al., 1987; Kitson \& Morgan, 1990). Therefore, successful adjustment requires divorcees to develop new identities that are not any longer based on the ties with the former spouse (Amato, $2000,2014)$. In other words, the process of building independence should lead to developing the socalled independent identity of a divorcee that is not tied to the status of being married to the ex-spouse (Yárnoz-Yaben, 2015) or to the lifestyle of the former marriage (Amato, 2000).

Though most divorced individuals eventually manage to free themselves of the post-divorce stress, 
the speed with which they regain good condition depends on a given individual's access to resources, which may take the form of income sufficient to live on, high-level education, support received from family, relatives, friends, and new romantic partners. Moreover, major individual resources useful in the adjustment process may include social skills, good coping, as well as the meanings that individuals attribute to divorce (some perceive divorce as a tragedy and a personal failure, while others see it as an opportunity to start life all over again). Unquestionably, positive views are much more common among the spouses who initiate the divorce process than in the spouses who are left by their partners (Amato, 2014). In general, the individuals who have a high level of various resources and interpret divorce in a positive way exhibit a tendency to adjust in a fairly short time after divorce (Amato, 2000).

Social support stands for an individual's interactions with the environment, which aim at protecting him or her against or mitigating the negative consequences caused by a stressful event (Szlachta, 2009). A distinction is made between received support and perceived support. Perceived social support is to be understood as the potential availability of support from a social network, whereas received social support comprises recipients' retrospective reports of actual support transaction (Scholz, Kliegel, Luszczynska, \& Knoll, 2012). The former refers to anticipating help from the social network at a time when it is needed and thus is often prospective in nature, whereas the latter refers to help rendered in a given time period and is always retrospective (Schwarzer, Knoll, \& Rieckmann, 2004). Perceived social support is based on the knowledge and beliefs of a person regarding where and from whom he or she may receive help, and whom he or she may count on in a difficult situation (Sęk \& Cieślak, 2005), and constitutes an important determinant of efficient coping with trauma (Ogińska-Bulik, 2013). These two different constructs (i.e. perceived and received social support) are often used in research (e.g. Norris \& Kaniasty, 1996; Haber, Cohen, \& Baltes, 2007). It has been proven that social support is associated with physical health (e.g. Cohen, 2004; Uchino, 2006), mental health indicators, and well-being (e.g. Schwarzer \& Leppin, 1991; Kawachi \& Berkman, 2001; Kasprzak, 2010).

In the literature devoted to divorce, social support is described as a relational factor affecting postdivorce adjustment that is crucial in building wellbeing after divorce (Amato, 2000; Clarke-Stewart \& Brentano, 2006; Demo \& Fine, 2010; Symoens et al., 2014; Thiriot \& Buckner, 1992). People who received support from their family or friends after divorce are better functioning psychologically and have fewer health issues (Clarke-Stewart \& Brentano, 2006; Gaffal, 2010). The number and quality of one's friends is highly important (Thiriot \& Buckner, 1992), particularly the support obtained from a new intimate relationship built after divorce (Amato, 2000; Demo $\&$ Fine, 2010). The intimate relation with one's best friend or a new partner contributes to a lower level of anxiety and depression, and affects the adjustment to the post-divorce situation. A strong social network of friends and family members contributes to experiencing feelings of depression less frequently (Symoens et al., 2014), whereas support received from a new partner constitutes a resource that provides protection against stressful situations and allows quicker restoration of balance after the experienced crisis (Amato, 2000). Dating after divorce is a significant element of adjusting to the post-divorce situation both for men and women, making them feel less lonely, facilitating perceiving divorce as a completed chapter of their lives, and resulting in a weaker attachment to the former spouse (Clarke-Stewart \& Brentano, 2006). The support received from parents is also important, especially financial support, ensured housing, assistance in taking care of children, and in coping with loneliness or isolation (Clarke-Stewart \& Brentano, 2006). Nevertheless, sometimes returning to parents' apartment after divorce and being dependent on one's parents may prove highly stressful and may lead to tension, overloading, or even conflicts (Beisert, 2000). Consequently, support provided by parents may subjectively be interpreted as having a positive effect on the divorcee's well-being but may also be considered as negative. It is important to know which elements of the social environment have a positive influence on health and well-being and which are destructive (Cohen, 2004). This is a legitimate question, as not all kinds of social relations and interactions have comparable effects on health, and they do not always predict improved health outcomes (Cohen, 2004; Nurullah, 2012). Research findings confirm that many of our close relationships may have both helpful and upsetting qualities (Uchino, 2006).

During the process of adjustment to a post-divorce situation, strong emphasis is put on the indirect mediating or moderating role of social support in the adaptation process (Amato, 2000; Demo \& Fine, 2010). In the post-divorce situation, benefits from the support received by individuals are doubled or expand to cover the children. This is caused by the fact that, as shown by research findings, children experience fewer difficulties if their parents receive extensive social support (Amato, 1994).

In the context of relational, health and tangible losses arising from a divorce, the number of sources of social support and its quality seem important (particularly the support provided by family members and friends), because they are natural sources of support for divorcees. However, it might happen that the support provided by the family of origin or relatives will have a negative impact on the post- 
divorce adjustment. This might occur if the immediate family adopts a negative attitude towards the marriage break-up. In that case, the divorcee has to face disapproval from his or her relatives, often becoming vulnerable to social isolation (Gaffal, 2010). As a result of divorce, social support may somewhat deteriorate.

Social support can provide direct protection against the impact of stressors or modify the way they are perceived (the so-called main effect - additive model) or serve as a buffer for adverse stressful outcomes (the stress buffer - interactive model), acting only when such an event occurs (Bovier, Chamot, \& Perneger, 2004; Cohen, 1992; Kaniasty, 2005; Sęk \& Cieślak, 2005; Szlachta, 2009). Thus, the impact of perceived support may be associated with changing the assessment of stressful events as a loss or a threat to perceiving the stressor as a challenge or a decreased intensity of negative original assessments (Sęk \& Cieślak, 2005), whereas according to the stress-buffering model of social support, recognizing the availability of support in the environment serves as a kind of protective buffer that mitigates the negative outcomes of stress (Cohen, 1992; Szlachta, 2009). This may also pertain to divorce-related stress. Positive outcomes of support may have a direct (owing to, e.g., mutual help) or an indirect character if the support contributes to coping with stress more effectively (Dwyer, 2005; Sęk \& Cieślak, 2005).

However, one ought to bear in mind that some stressful events mobilize the support network, while others deteriorate access to the support network (Kaniasty \& Norris, 1993). According to research, events such as death of the spouse or a severe illness enhance social support. Nevertheless, there are also critical or even traumatic events that deteriorate social support. These often include private or ambiguous events related to social stigma and shame (e.g., victims of sexual abuse and rape - cf. Punamäki, Komproe, Qouta, El-Masri, \& de Jong, 2005). Such a situation can be exemplified by divorce, with an increased level of stress caused by binding network norms related to the lack of acceptance or even stigmatization of divorcees (Cohen, 1992). Therefore, not all serious events in the lives of individuals provoke sympathy and willingness to provide support in the same way. Divorce may trigger certain feelings, and hence the weakening of support.

The notion of support deterioration is described in the literature in relation to experiencing natural disasters (Kaniasty \& Norris, 2005). It stands for a process of change in social relations characterized by a weakening of contact with others, a feeling of loneliness and intensifying interpersonal conflicts. In a situation of natural disaster, the growing deterioration of support pertains above all to perceived support, i.e., the belief that help will be available if needed (Kaniasty \& Norris, 2005). The deteriora- tion of support has a negative impact on emotional functioning and may exacerbate psychopathological symptoms, a direct result of which is further deterioration of support.

The support deterioration model can be helpful in explaining the critical event of divorce, which in itself leads to a reduction in the number of or a loss of significant sources of support (Sęk \& Cieślak, 2005). This is due to the fact that divorce is also a difficult situation for the friends and family of a separating couple. Often, people attached to a given married couple - family, friends, acquaintances, neighbors - do not want to take either side in the event of divorce, preferring to remain uninvolved in the conflict. Friends and acquaintances may also find it hard to understand that divorcees experience grief for an extensive period of time following the loss of their spouse due to divorce (Power, 1996). According to some researchers, a protective factor can take the form of support provided by individuals who experienced divorce themselves available in the immediate support network (Clarke-Stewart \& Brentano, 2006). Studies conducted by Symoens and colleagues (2014) showed divorcees to be disadvantaged in social relations compared to married couples. Thus, perceived social support appears to be a significant mediator of the relationship between marital status and psychological well-being. In comparison to married persons, divorced individuals recognized lower levels of perceived social support and, consequently, experienced significantly poorer psychological health and well-being (Soulsby \& Bennett, 2015). Moreover, the study also proved that most divorcees experienced network losses primarily briefly after the divorce, with half of the divorced subjects not compensating for these losses in later years (Terhell et al., 2004). The greatest impact for divorcees is exerted by socio-emotional support, i.e., maintaining social contacts, the presence of close ones, companionship, the opportunity of being heard, and experiencing closeness (Clarke-Stewart \& Brentano, 2006).

In conclusion, empirical studies on the beneficial role of social support conducted so far are not uniform (Punamäki et al., 2005). On the one hand, the review of studies confirms the massive impact of social support during the process of adjusting to post-divorce changes and achieving psychological well-being, while on the other, the researchers prove the situation regarding support provided to divorcees to be adverse. Hence, an important research task is to explain the meaning of social support for the psychological well-being of divorcees.

The main objective of this study was to examine two basic questions: what are the sources of support available to divorcees, and is the perceived social support a mediator of the relationship between the sense of loss associated with divorce and the psychological well-being of individuals after divorce? 


\section{PARTICIPANTS AND PROCEDURE}

Recruitment to the study was conducted in selected family diagnostic and consultative centers throughout Poland, psychological and pedagogical counseling centers, family assistance centers and other institutions that handle child and family issues in Silesia. The main criterion for inclusion in the study was that the person (woman or man) was divorced. Participants were recruited by the employees of the above-mentioned institutions, who in most cases were psychologists or pedagogues. They provided exhaustive information about the purpose of the study. Divorcees who agreed to participate in the study received a paper-pencil set of questionnaires to complete. All participants were informed that the survey was entirely voluntary and that they had the right to withdraw at any time. Participants were given written instructions emphasizing the anonymous aspects of the study.

The sample comprised 157 individuals after divorce: $120(76.40 \%)$ women and $37(23.60 \%)$ men. The mean age of the respondents was 41 years $(M=41.29, S D=8.86)$. The youngest subject was 24 years old, whereas the eldest was 71 years old. The mean time since the divorce was over 6 years $(M=6.40, S D=6.30)$. The majority of subjects in the sample were people who had initiated the divorce by filing a divorce petition with the court (initiators = $64.70 \%$; non-initiators $=35.30 \%$ ).

Most of the respondents were residents of medium-sized ( $n=58,36.50 \%)$ or small-sized cities ( $n=39$, $24.50 \%)$, whereas $28(17.60 \%)$ of the respondents resided in large cities or in the country ${ }^{1}(n=33,21.00 \%)$. The majority of the respondents had completed academic education $(n=76,47.80 \%)$ or secondary education $(n=56,35.30 \%)$; others had completed vocational education $(n=25,15.70 \%)$, while only $2(1.30 \%)$ had basic education. One hundred twenty-nine respondents $(81.10 \%)$ were employed, whereas $25(15.70 \%)$ were unemployed.

The average duration of marriage was 11 years $(M=10.80, S D=6.80)$. A vast majority of the respondents declared the marriage that ended in divorce to be their first, with only 3 individuals reporting having dissolved their second marriage. Seventy-eight respondents $(47.80 \%)$ stated that they were not involved in any other romantic relationship after divorce and $51(32.10 \%)$ individuals reported that they were in a new romantic relationship, while $29(18.20 \%)$ individuals had re-married.

The majority of the respondents had one child ( $n=76,47.80 \%)$ or two children $(n=51,32.10 \%)$. Twelve respondents had three or more children $(7.50 \%)$, while $15(9.40 \%)$ had no children ${ }^{2}$. Half of the respondents stated that they were the custodial parent $(n=84,52.80 \%)$ with physical custody of a child since divorce, whereas one fifth of the respondents
( $n=31,19.50 \%)$ reported the other parent to be a custodial parent. Six respondents $(3.80 \%)$ co-parented their children, while in the case of five $(3.10 \%)$ individuals their children were adult. Twenty-eight respondents $(17.60 \%)$ had children from a new relationship.

Most respondents considered their current material situation to be average (60 individuals, $37.80 \%$ ) or good (58 individuals, $36.50 \%$ ). Only five respondents $(3.10 \%)$ claimed their current material situation was very poor, while $19(11.90 \%)$ reported it to be poor. Seventeen individuals $(10.70 \%)$ stated that they were in a very good material situation at that time.

\section{MEASURES}

Sense of loss associated with divorce. The sense of loss associated with divorce was measured with the original Sense of Loss Scale (DS) devised for this research. It consists of 6 items rated on a 4-point response scale with scores ranging from 0 (strongly disagree) to 3 (strongly agree). The sum of the item scores is a measure of the sense of loss associated with divorce. The lowest possible DS score is 0 . The highest possible DS score is 18 . The higher the score, the greater is the sense of loss. Individual items in the DS scale refer to the sense of anger, injustice, sadness, grief, loneliness, horror, guilt, and non-acceptance of the situation. The internal consistency of the scale in the current sample was $\alpha=.80$, indicating a relatively high consistency of responses to individual questions. The Sense of Loss Scale has a single-factor structure.

Perceived social support. The perceived social support variable was measured using the Polish version of the Interpersonal Support Evaluation List (ISEL) adapted by Szlachta (2009), which is a 40-item instrument. The respondent rates individual statements using a 4-point scale ranging from definitely false to definitely true. The questionnaire serves the purpose of measuring perceived availability of four forms of social support (appraisal support, tangible support, self-esteem and belonging support), which according to the authors of the instrument play an important role in coping with various stressful situations (Cohen \& Hoberman, 1983; Szlachta, 2009). Internal consistency of the Polish adaptation of ISEL (Cronbach's $\alpha$ ) is .90 for the global scale and from .69 to .79 for the subscales (Szlachta, 2009). The global scale score serves for measuring the overall perceived social support. The aim of the appraisal support subscale is to measure the perceived availability of people with whom one can discuss one's difficulties and problems, which contributes to a better understanding of one's situation and receiving feedback on the efficiency of undertaken actions. The tangible support subscale serves for measuring the perceived availability of tangible and financial assistance, as 
well as specific direct assistance for the person in need. The self-esteem support subscale serves for measuring perceived availability of positive comparison with others, giving the individual a belief that he or she is accepted, appreciated or admired by others. The belonging support subscale serves for measuring the perceived presence of other people with whom a given individual can spend his or her time engaging in some activities together (Szlachta, 2009). In the Polish adaptation, this instrument is characterized by construct validity, while its factor structure is not consistent with the original version. The structure of the Polish version of ISEL and the original structure of this instrument are not thoroughly convergent; thus it is recommended to interpret the ISEL global scale score and to take particular care when analyzing scores for individual subscales. The sum of the item scores is an overall measure of perceived social support. The lowest possible ISEL score is 40 . The highest possible ISEL score is 160 . The reliability of the ISEL in the current study was $\alpha=.95$.

Psychological well-being. The psychological wellbeing was assessed with the Oxford Happiness Questionnaire (OHQ) (Hills \& Aryle, 2002) in the Polish adaptation by Kołodziej and Przybyła-Basista (2013). The Polish version of the instrument comprises 23 statements to which the respondent provides answers on a 6-point response scale with 1 standing for strongly disagree and 6 for strongly agree. The questionnaire serves for investigating contentment with life, general satisfaction with the course of life and the intensity of positive emotions, but also for assessing the sense of meaning and control in life, assessing life as good and valuable. The reliability of the Polish adaptation of the Oxford Happiness Questionnaire OHQ-23 measured with Cronbach's $\alpha$ is .90. The instrument is stable. Results of exploratory factor analysis and confirmatory factor analysis of the 23-item version of the OHQ prove the validity of adopting the two-factor model. Two of the distinguished factors were named: contentment with life and empowerment (the first factor) and the sense of meaning and control (the second factor). The fact of the two factors being distinguished does not indicate lack of homogeneity of the investigated construct. It is possible to obtain an overall score in the questionnaire and scores for individual subscales. The sum of the item scores is an overall measure of well-being, with high scores indicating greater well-being. The lowest possible OHQ-23 score is 23. The highest possible OHQ-23 score is 138 . In the present study the OHQ-23 had good reliability; $\alpha=.91$.

Sociodemographic data. The respondents also completed a questionnaire regarding sociodemographic data, information on the family, as well as the divorce and post-divorce situation.

Statistical analysis was performed using SPSS 22 . The indirect effect was tested using a bootstrapping technique. Bootstrapping is a non-parametric procedure that relies on random sampling with replacement. This technique produces point estimates and bias-corrected confidence intervals for the indirect effect. Mediation analysis was conducted using the PROCESS macro for IBM SPSS Statistics version 22.0, with 5,000 bootstraps and bias correction (Hayes, 2013). The acceptable confidence interval was $95 \%$. When it does not include zero, mediation is statistically significant.

\section{RESULTS}

\section{SOURCES OF SUPPORT}

In order to answer the question about the basic sources of support of individuals after divorce, the results of the personal questionnaires were subjected to analysis. A vast majority of respondents reported the main sources of support to be their parents $(n=90)$, as well as friends and acquaintances $(n=84)$. About one third of the respondents $(n=54)$ claimed their siblings to be their source of support, and a similar number of respondents $(n=50)$ indicated their children as a source of support. About a quarter of the respondents $(n=38)$ found a source of support in their new romantic partner. Specific values are presented in detail in Figure 1.

Another specific question pertained to the number of sources of support used by divorcees. About a quarter of the respondents $(25.80 \%)$ indicated a single source of support. Another quarter of the respondents indicated two sources $(24.50 \%)$, and nearly one third of the divorcees made use of three sources of support (29.60\%). Simultaneous support received from four sources was experienced by $12.60 \%$ of the respondents, whereas support from five or more sources was experienced by only $3.10 \%$ of the respon-

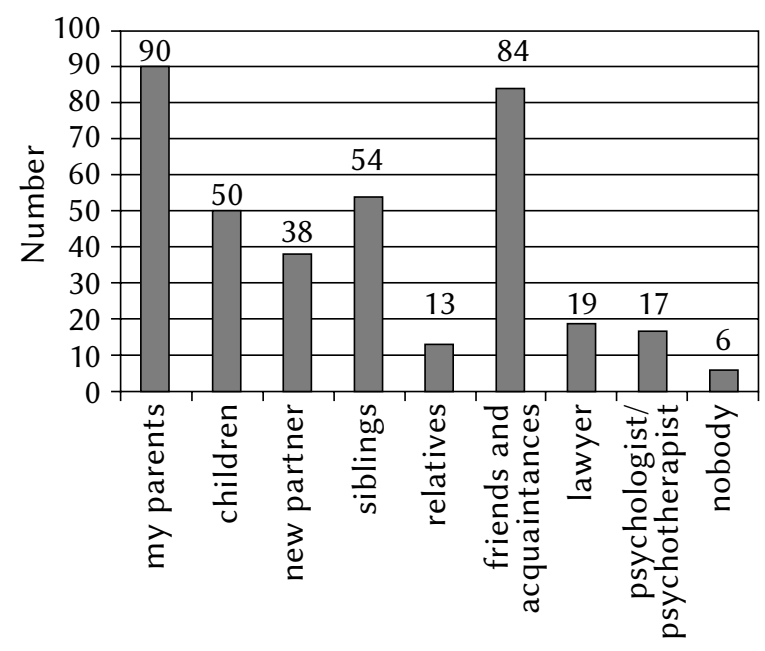

Figure 1. Source of support after divorce indicated by respondents. 


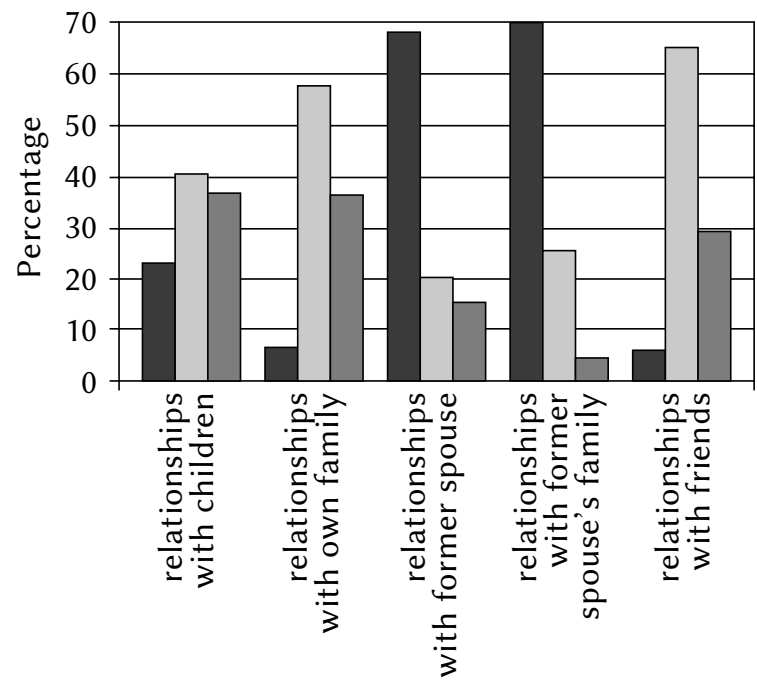

$\square$ improvement $\square$ no change $\square$ deterioration

Figure 2. Assessment of impact exerted by divorce on social relationships.

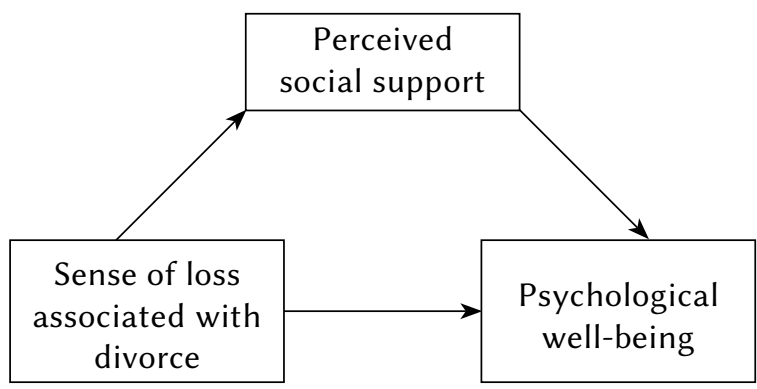

Figure 3. Perceived social support as a mediator of relationships between sense of loss associated with divorce and psychological well-being: graphical presentation of the examined model.

dents. Few respondents (4.40\%) declared lack of any source of support whatsoever.

In their assessment of the impact exerted by divorce on specific social relationships, most of the respondents claimed that their relations with friends and their own family had not changed after divorce (64.90\% for friends and $57.40 \%$ for family) or even improved (29.10\% for friends and $35.80 \%$ for family). A graphic representation of the results is shown in Figure 2.

On the other hand, the respondents experienced a deterioration of interpersonal relations in the field of contacts with the former spouse's family (69.80\%) and, above all, with the former spouse himself (67.80\%). The highest diversity characterized the assessment of the impact of divorce on relationships with one's children: $23.10 \%$ of the respondents experienced a deterioration in relations with their children, $40.30 \%$ reported no changes, whereas $36.60 \%$ claimed that relations with their children had improved.

\section{SOCIAL SUPPORT AS A MEDIATOR}

Subsequently, we verified the assumption about the role of support as a mediator in building the well-being of individuals after divorce. Figure 3 illustrates the examined model.

Selected statistical parameters such as means, standard deviations, and correlations between the variables sense of loss associated with divorce, perceived social support and psychological well-being are presented in Table 1. Data analysis shows that the variables are correlated. The sense of loss associated with divorce is negatively correlated with perceived social support and psychological well-being. The correlation between the perceived social support and psychological well-being is positive.

The analyzed mediation model involves time since divorce and gender as controlled variables. It was assumed that time may affect the ability to achieve well-being after experiencing a crisis. In regard to gender, numerous reports point to the impact of gender on forming and maintaining social networks and its effect on contentment with life. The adopted mediation model together with its covariants proved statistically significant. It explains $44 \%$ of variance $\left(F=22.59, d f_{1}=4, d f_{2}=113\right.$, adj. $\left.R^{2}=.44, p<.001\right)$. Controlled variables, that is the time since divorce and gender, did not reach the significance levels.

The correlation between the sense of loss associated with divorce and the perceived social support proved statistically significant: $b=-1.91, \mathrm{CI}=<-2.74$; $-1.08>, p<.001$. The correlation between perceived social support and psychological well-being also proved significant: $b=0.57, \mathrm{CI}=<0.42 ; 0.72>, p<.001$. The total effect of the sense of loss on well-being with the indirect effect not being controlled is significant

Table 1

Means, standard deviations, Cronbach's $\alpha$ and correlations between variables

\begin{tabular}{lrccccc}
\hline & $M$ & $S D$ & Cronbach's $\alpha$ & 1 & 2 & 3 \\
\hline 1. Sense of loss & 6.14 & 4.40 & .80 & - & - & - \\
2. Perceived social support & 127.33 & 21.60 & .94 & $-.34^{* * *}$ & - & - \\
3. Psychological well-being & 103.51 & 21.41 & .91 & $-.35^{* * *}$ & $.63^{* * *}$ & - \\
\hline Note. ${ }^{* *} p<.001$, correlations $r$-Pearson. & & &
\end{tabular}


$(b=-1.89, \mathrm{CI}=<-2.70 ;-1.08>, p<.001)$, whereas the direct impact of the sense of loss on psychological well-being with the controlled indirect effect is also significant, yet weaker: $b=-0.80, \mathrm{CI}=<-1.52$; $-0.08>, p<.05$. The results also show that the indirect effect of perceived support on well-being is statistically significant: $b=-1.08, \mathrm{CI}=<-1.67 ;-0.61>$, $p<.05$. The model is presented in Figure 4 .

The perceived social support can be considered a significant partial mediator for the relationship between the sense of loss associated with divorce and psychological well-being. The Sobel test confirmed the presence of the analyzed indirect effect: $z=-3.89$, $p<.001$.

\section{DISCUSSION}

Our study was focused on explaining the role of perceived social support in the post-divorce period as a mediator of the relationship between the sense of loss associated with marriage break-up and psychological well-being of individuals after divorce. The indirect effect of social support in building well-being after experiencing the loss associated with marriage break-up has been proven. This means that for both divorced women and men perceived social support is one of the main sources of support with a significant effect on achieving psychological well-being after divorce, as it is related to a mitigated negative effect of the sense of loss associated with marriage break-up. Moreover, it was also found that for the vast majority of the respondents the main source of support is parents, as well as friends and acquaintances. For about one third of the respondents the source of support was siblings, as well as their own children.

The conducted studies correspond well with the current lines of empirical research aiming at explaining how complex mechanisms of influence operate, in which social support plays the role of a mediator or a moderator. The analyses presented in this article correspond to the recent research findings which prove that perceived social support serves as a mediator of the relationship between marital status and psychological well-being, with a lower level of support being recognized by divorcees than married individuals (Soulsby \& Bennett, 2015; Symoens et al., 2014). In our studies, social support played the role of a partial mediator. Therefore, a question should be asked how it can be explained.

It seems that the relationship between the sense of loss associated with marriage break-up and psychological well-being can be strong enough to allow other variables - apart from social support - to play a significant mediating role. For this very reason, social support acted as a partial mediator and not a full mediator. And thus, for instance, resources that reside in the individual such as social skills and good

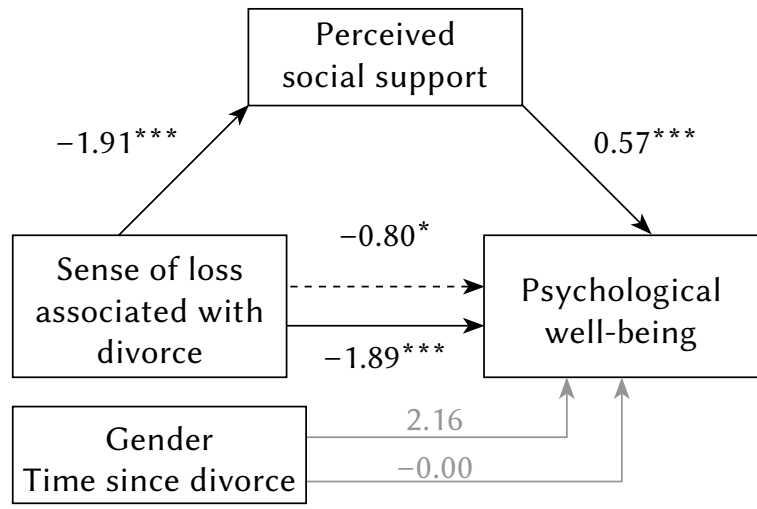

Note. ${ }^{*} p<.05,{ }^{* * *} p<.001$. Dotted line indicates total effect: not controlling for the mediator. There are unstandardized coefficients $b$ under the lines.

Figure 4. Perceived social support as a mediator of relationships between sense of loss associated with divorce and psychological well-being: results of mediation.

coping with post-divorce stress can facilitate the adjustment and the achievement of well-being (cf. Amato, 2014).

Divorcees face specific challenges associated with the necessity to overcome emotional attachment to the former partner, the sense of loneliness caused by the loss of former social networks and coping with the co-parenting conflict (Halford \& Sweeper, 2013). Tackling all these challenges can be facilitated by means of one's relational resources such as support from the immediate family and friends. Our study proved that the vast majority of the respondents found such support in their parents, as well as friends and acquaintances. For about one quarter of the respondents the source of support was their new romantic partners. According to Amato (2014), the speed of recovery depends on people's access to resources, with the support received from the immediate family and from new romantic partners being highly important. In general, the results of our study support these data. Relations with friends and family constitute a protective factor for individuals after divorce. Acquaintances, friends and family become the most natural support network in the context of the loss of a marital relationship (Clarke-Stewart \& Brentano, 2006; Gaffal, 2010).

Even though it is no surprise that according to our results over two thirds of the respondents experienced a deterioration of the interpersonal relations with the families of their former husbands, the deterioration of relations with their own children (nearly a quarter of all the respondents) gives rise to concern. The presence of children in a relationship is quite a challenge for divorced parents, as it requires maintaining contacts between the separated partners. Such contacts usually exacerbate existing adjustment issues, particularly those related to severing ties with the former romantic partner. It is more common for 
children to reside with their mother than with their father following divorce, whereas men often exhibit a tendency to reduce contact with their children after separation, associated with considerable distress in men (cf. Halford \& Sweeper, 2013). What is more, conflicts pertaining to co-parenting are the main source of anxiety and concerns of their former partners (Halford \& Sweeper, 2013).

It is worth paying attention to yet another result of this study, namely, the negative correlation between the sense of loss associated with marriage break-up, perceived social support, and psychological well-being. This fact can be explained by the concept of deterioration of social support (Kaniasty \& Norris, 2005), according to which in a situation of severe and prolonged stress the individual gives a negative assessment of sources of available social support. Divorce is one such critical event that may lower social support (Cohen, 1992). In the light of the obtained results, further research ought to be planned, and a comparison of perceived social support and received social support from various sources ought to be made, with an attempt to determine which kind of support is more adequate depending on the stage of the process of adjusting to the new life situation. This is due to the fact that in the short term divorce causes a decrease in psychological, social, and physical well-being. In the long term - after several years - most individuals adapt well to their new lives. However, a significant minority remain seriously troubled (Amato, 2010). Moreover, the dynamics of post-divorce changes indicate changes in the network dynamics. Most divorcees experience a loss of the support network briefly after the divorce, with half of them never regaining these contacts in the years following the divorce (Terhell et al., 2004). Hence, it is also worth planning longitudinal studies on the effect of social support (both perceived and received) on the adjustment process.

The results of our study also showed that time since divorce, treated as a controlled variable in the model, was not associated with the psychological well-being of individuals after divorce. Similarly, gender was not a statistically significant variable. These results ought to be replicated with an increased number of divorced men participating in the study. The literature indicates research reports claiming that gender differences are observed. Divorced men exhibited a greater tendency to suffer from emotional loneliness compared to women. What is more, men tend to have a smaller support network (Dykstra \& Fokkema, 2007). Researchers point to the need to differentiate social and emotional loneliness among divorcees. Social loneliness consists in having a relatively small social support network, whereas emotional loneliness, which pertains most of all to divorced individuals, is characterized by suffering caused by absence of a partner (Dykstra \& Fokkema, 2007).
Nevertheless, our investigations presented here also have some limitations. First of all, the study results ought to be interpreted with a degree of caution. The conclusions can be applied with a greater degree of confidence to divorced women than men due to the over-representative sample of female respondents in the study. The male respondents of the study were greatly outnumbered by the female respondents. Moreover, the study was cross-sectional and not longitudinal. Additionally, the respondents varied in terms of time since the divorce. Such a selection of divorced individuals for the sample was dictated by difficulties in the accessibility of the respondents.

\section{CONCLUSIONS}

The collected evidence proves that perceived social support is an important resource that has a significant indirect effect on the psychological well-being of individuals after divorce. Thus, social support may be an important variable that ought to be taken into consideration in designing interventions that allow minimization of the negative consequences of a transition out of marriage (Soulsby \& Bennett, 2015). The study constitutes a valuable contribution to the discussion on the functioning of social support in the process of adjusting to new life conditions and achieving well-being after divorce.

\section{ENDNOTES}

1 Possible differences in percentage values result from minor system data deficiencies.

2 In 33 cases the data about children were missing in the questionnaires.

\section{References}

Amato, P. R. (1994). Life-span adjustment of children to their parents' divorce. The Future of Children. Children and Divorce, 4, 143-164. doi: 10.2307/1602482

Amato, P. R. (2000). The consequences of divorce for adults and children. Journal of Marriage and Family, 62, 1269-1287. doi: 10.1111/j.17413737.2000.01269.x

Amato, P. R. (2010). Research on divorce: Continuing trends and new developments. Journal of Marriage and Family, 72, 650-666. doi: 10.1111/j.17413737.2010.00723.x

Amato, P. R. (2014). The consequences of divorce for adults and children: An update. Društvena Istraživanja / Journal for General Social Issues, 23, 5-24. doi: 10.5559/di.23.1.01 
Beisert, M. (2000). Rozwód. Proces zmagania się z kryzysem [Divorce. The process of confronting crisis]. Poznań: Wydawnictwo Fundacji Humaniora.

Błażek, M. (2014). Rozwód jako sytuacja kryzysowa $\mathrm{w}$ rodzinie [Divorce as a crisis situation in a family]. In I. Janicka \& H. Liberska (eds.), Psychologia rodziny [The family psychology] (pp. 459-481). Warszawa: PWN.

Bohannan, P. (1970). The six stations of divorce. In P. Bohannon (ed.), Divorce and after (pp. 29-55). New York: Doubleday.

Bovier, P. A., Chamot, E., \& Perneger, T. V. (2004). Perceived stress, internal resources, and social support as determinants of mental health among young adults. Quality of Life Research, 13, 161170. doi: 10.1023/B:QURE.0000015288.43768.e4

Clarke-Stewart, A., \& Brentano, C. (2006). Divorce: causes and consequences. New Haven-London: Yale University Press.

Cohen, S. (1992). Stress, social support, and disorder. In H. O. Veiel \& U. Bauman (eds.), The meaning and measurement of social support (pp. 109-124). New York: Hemisphere Press.

Cohen, S. (2004). Social relationships and health. American Psychologist, 59, 676-684. doi: 10.1037/0003-066X.59.8.676

Cohen, S., \& Hoberman, H. (1983). Positive events and social supports as buffers of life change stress. Journal of Applied Social Psychology, 13, 99-125.

Coleman, M., Ganong, L., \& Leon, K. (2006). Divorce and postdivorce relationships. In A. L. Vangelisti \& D. Perlman (eds.), The Cambridge handbook of personal relationship (pp. 157-173). Cambridge: University Press.

Crane, D. R. (2002). Podstawy terapii matżeństw [Fundamentals of marital therapy]. Gdańsk: Gdańskie Wydawnictwo Psychologiczne.

Demo, D. H., \& Fine, M. A. (2010). Beyond the average divorce. Los Angeles-London-New Delhi-Singapore: Sage.

Dwyer, D. (2005). Bliskie relacje interpersonalne [Interpersonal relationships]. Gdańsk: GWP.

Dykstra, P. A., \& Fokkema, T. (2007). Social and emotional loneliness among divorced and married men and women: Comparing the deficit and cognitive perspectives. Basic and Applied Social Psychology, 29, 1-12. doi: 10.1080/01973530701330843

Gaffal, M. (2010). Psychosocial and legal perspectives of marital breakdown. Berlin Heidelberg: Springer-Verlag.

Haber, M. G., Cohen, J. L., \& Baltes, B. B. (2007). The relationship between self-reported received and perceived social support: a meta-analytic review. American Journal of Community Psychology, 39, 133-144. doi: 10.1007/s10464-007-9100-9

Halford, W. K., \& Sweeper, S. (2013). Trajectories of adjustment to couple relationship separation. Family Process, 52, 228-243. doi: 10.1111/ famp. 12006
Hayes, A. F. (2013). Introduction to mediation, moderation, and conditional process analysis: a regression-based approach. New York-London: The Guilford Press.

Hills, P., \& Argyle, M. (2002). The Oxford Happiness Questionnaire: a compact scale for measurement of psychological well-being. Personality and Individual Differences, 33, 1073-1082. doi: 10.1016/ S0191-8869(01)00213-6

Kaniasty, K. (2005). Social support and traumatic stress. PTSD Research Quarterly, 16, 1-3.

Kaniasty, K., \& Norris, F. H. (1993). A test of the social support deterioration model in the context of natural disaster. Journal of Personality and Social Psychology, 64, 395-408. doi: 10.1037/00223514.64.3.395

Kaniasty, K., \& Norris, F. H. (2005). „Wzlot i upadek utopii": mobilizacja i deterioracja wsparcia społecznego w sytuacjach klęsk żywiołowych [The rise and fall of utopia: Mobilization and deterioration of social support in the aftermath of natural disasters]. In H. Sęk \& R. Cieślak (eds.), Wsparcie spoteczne, stres i zdrowie [Social support, stress and health] (pp. 123-138). Warszawa: PWN.

Kasprzak, E. (2010). Perceived social support and life-satisfaction. Polish Psychological Bulletin, 41, 144-154. doi: 10.2478/v10059-010-0019-x

Kawachi, I., \& Berkman, L. F. (2001). Social ties and mental health. Journal of Urban Health: Bulletin of New York Academy of Medicine, 78, 458-467.

Kiecolt-Glaser, J. K., Fisher, L. D., Ogrocki, P., Stout, J. C., Speicher, C. E., \& Glaser, R. (1987). Marital quality, marital disruption, and immune function. Psychosomatic Medicine, 49, 13-34.

Kitson, G. C., \& Morgan, L. A. (1990). The multiple consequences of divorce: A decade review. Journal of Marriage and the Family, 52, 913-924.

Kołodziej, A., \& Przybyła-Basista, H. (2013). Oksfordzki Kwestionariusz Szczęścia - polska adaptacja narzędzia do badania dobrostanu: wyniki wstępne [Oxford Happiness Questionnaire - Polish adaptation of the instrument for measuring well-being. Preliminary results]. Ist International Conference on Positive Psychology in Poland (poster). Sopot: SWPS Wydział Zamiejscowy (unpublished paper).

Norris, F. H., \& Kaniasty, K. (1996). Received and perceived social support in times of stress: A test of the social support deterioration deterrence model. Journal of Personality and Social Psychology, 71, 498-511. doi: 10.1037/0022-3514.71.3.498

Nurullah, A. S. (2012). Received and provided social support: A review of current evidence and future directions. American Journal of Health Studies, 27, 173-188.

Ogińska-Bulik, N. (2013). The role of social support in posttraumatic growth in people struggling with cancer. Health Psychology Report, 1, 1-8. doi: 10.5114/hpr.2013.40464 
Perrig-Chiello, P., Hutchison, S., \& Morselli, D. (2015). Patterns of psychological adaptation to divorce after a long-term marriage. Journal of Social and Personal Relationships, 32, 386-405. doi: 10.1177/0265407514533769

Power, M. R. (1996). Stages of separation. Australian Journal of Family Law, 10, 143-162.

Przybyła-Basista, H. (2006). Mediacje rodzinne w konflikcie rozwodowym. Gotowość i opór matżonków a efektywność procesu mediacji [Family mediation in divorce conflict: Spouses' readiness and resistance to mediation vs. effectiveness of the mediation process]. Katowice: Wydawnictwo Uniwersytetu Śląskiego.

Punamäki, R., Komproe, I., Qouta, S., El-Masri, M., \& de Jong, J. T. (2005). The deterioration and mobilization effects of trauma on social support: Childhood maltreatment and adulthood military violence in a Palestinian community sample. Child Abuse \& Neglect, 29, 351-373. doi: 10.1016/j. chiabu.2004.10.011

Scholz, U., Kliegel, M., Luszczynska, A., \& Knoll, N. (2012). Associations between received social support and positive and negative affect: evidence for age differences from a daily-diary study. European Journal of Aging, 9, 361-371. doi: 10.1007/s10433012-0236-6

Scourfield, J., \& Evans, R. (2014). Why might men be more at risk of suicide after a relationship break down? Sociological insights. American Journal of Men's Health, 9, 380-384. doi: $10.1177 / 155779883145463395$

Schwarzer, R., Knoll, N., \& Rieckmann, N. (2004). Social support. In A. Kaptein \& J. Weinmann (eds.), Health psychology (pp. 158-182). Oxford: Blackwell.

Schwarzer, R., \& Lepin, A. (1991). Social support and health: A theoretical and empirical overview. Journal of Social and Personal Relationships, 8, 99-127.

Sęk, H., \& Cieślak, R. (2005). Wsparcie społeczne sposoby definiowania, rodzaje i źródła wsparcia, wybrane koncepcje teoretyczne [Social support - ways of defining, the types and sources of support, selected theoretical concepts]. In H. Sęk \& R. Cieślak (eds.), Wsparcie społeczne, stres i zdrowie [Social support, stress and health] (pp. 11-29). Warszawa: PWN.

Soulsby, L. K., \& Bennett, K. M. (2015). Marriage and psychological wellbeing: The role of social support. Psychology, 6, 1349-1359. doi: 10.4236/ psych.2015.611132

Symoens, S., Van de Velde, S., Colman, E., \& Bracke, P. (2014). Divorce and the multidimensionality of men and women's mental health: The role of social-relational and socio-economic conditions. Applied Research in Quality of Life, 9, 197-214. doi: 10.1007/s11482-013-9239-5
Szlachta, E. (2009). Próba adaptacji i walidacji polskiej wersji The Interpersonal Support Evaluation List (ISEL) [The adaptation and preliminary validation of the Polish version of the Interpersonal Support Evaluation List (ISEL)]. Przegląd Psychologiczny, 52, 433-451.

Terhell, E. L., van Groenou, M. I. B., \& van Tilburg, T. (2004). Network dynamics in the long-term period after divorce. Journal of Social and Personal Relationships, 21, 719-738. doi: 10.1177/ 0265407504047833

Thiriot, T. L., \& Buckner, E. T. (1992). Multiple predictors of satisfactory post-divorce adjustment of single custodial parents. Journal of Divorce \& Remarriage, 17, 27-48. doi: 10.1300/J087v17n01_03

Thuen, F. (2001). Psychiatric symptoms and perceived need for psychiatric care after divorce. Journal of Divorce \& Remarriage, 34, 61-76. doi: 10.1300/J087v34n01_04

Uchino, B. N. (2006). Social support and health: A review of physiological process potentially underlying links to disease outcomes. Journal of Behavioral Medicine, 29, 377-387. doi: 10.1007/ s10865-006-9056-5

Yárnoz-Yaben, S. (2013). Forgiveness, adjustment to divorce and support from the former spouse in Spain. Journal of Child and Family Studies, 24, 289-297. doi: 10.1007/s10826-013-9835-x

Zafar, N., \& Kausar, R. (2014). Emotional and social problems in divorced and married women. FWU Journal of Social Sciences, 8, 31-35. 